\title{
KNOWLEDGE SHARING MODEL AMONG ACADEMIC STAFFS IN UNIVERSITIES
}

\author{
Semlinda Juszandri Bulan and Dana Indra Sensuse \\ Faculty of Computer Science, Universitas Indonesia \\ Depok, Indonesia, 16424
}

Email: semlinda@yahoo.com

\begin{abstract}
Knowledge sharing is very important in an organization, one of the effects of these activities is to improve the performance of the organization. In education sector, effective knowledge sharing among academic staff can improve the performance of a university. The aim of this research was to propose a model for knowledge sharing among academic staff. Factors influencing knowledge sharing consists of individual factors, organizational factors and technological factors. These three factors can improved university performance.
\end{abstract}

Keywords: individual factor, organizatonal factor, technology factor, knowledge sharing, university performance.

\begin{abstract}
Abstrak
Berbagi pengetahuan sangat penting dalam sebuah organisasi. Salah satu dampak dari kegiatan ini adalah untuk meningkatkan kinerja organisasi. Dalam dunia pendidikan, knowledge sharing yang efektif diantara staf akademik dapat meningkatkan kinerja dari perguruan tinggi. Tujuan dari penelitian ini adalah mengusulkan sebuah model knowledge sharing diantara staf akademik. Faktor-faktor yang memengaruhi knowledge sharing diantara staf akademik terdiri dari faktor individu, faktor organisasi dan faktor teknologi. Ketiga faktor ini dapat meningkatkan performance dari perguruan tinggi.
\end{abstract}

Kata kunci: faktor individu, faktor organisasi, faktor teknologi, knowledge sharing, performance universitas.

\section{Introduction}

Knowledge sharing within an organization is a very important thing. This issue arises when a person leaves the organization with his/her intellectual property without sharing their knowledge (knowledge walkouts) [1]. This would be very detrimental to the organization.

Knowledge sharing occurs at the level of individuals and organizations. For individual employees, knowledge sharing is to talk to their colleagues to help them get things could be done better, faster, or more efficiently. For an organization, knowledge sharing is to capturing, organizing, reusing and transferring experiencebased knowledge within the organization so that knowledge is available that can be used by others in the business [2].
In a knowledge-based organization such as a university or college, knowledge sharing is very important because most of the employees are knowledge workers. In the world of education, effective knowledge sharing will lead scholars to realize and develop their full potential.

Educational institutions play an important role in knowledge creation. Tacit knowledge is created or obtained by the academics, embedded in their minds, is the intellectual capital of the institution [3]. Competitive advantage can be obtained if the knowledge be shared to those who need it so as to obtain benefits.

A number of studies have clearly shown that knowledge sharing is an important process because it allows an organization to improve innovation and organizational performance [4]. Therefore, knowledge sharing is important to the 
success and the development of an educational institution.

\section{Literature Review}

\subsection{Knowledge}

Knowledge is a set of information to the decision-making and actions that lead to the usefulness and purpose [4]. Knowledge is a habit, expertise, skill, knowledge and understanding gained from the experience, training or through a learning process. It can be concluded that knowledge is a collection of information that has been through the experience.

"Knowledge is human understanding of a specialized field of interest that has been acquired through study and experience" [5]. According to them knowledge is a human understanding of something special and important which acquired through learning and experience. Knowledge is not information, and information is not the data.

Knowledge is divided into six types [4], namely:

1. Procedural knowledge

"Procedural knowledge, in contrast, focuses on beliefs relating sequence of steps or actions to desired (or undesired) outcomes".

2. Declarative knowledge

"Declarative knowledge focuses on beliefs about relationship among variables".

3. Tacit knowledge

"Tacit knowledge includes insights, intuitions, and hunches. This knowledge is difficult to express and formalize, and therefore difficult to share. Tacit knowledge is more likely to be personal and based on individual experiences and activities".

4. Explicit knowledge

"Explicit knowledge typically refers to knowledge that has been expressed into words and numbers. Such knowledge can be shared formally and systematically in the form of data, specifications, manuals, drawings, audio and videotapes, computer programs, patents, and the like"

5. General knowledge

"General knowledge is possessed by a large number of individuals and can be transferred easily across individuals".

6. Specific knowledge

"Specific knowledge is possessed by a very limited number of individuals, and is expensive to transfer"

\subsection{Knowledge Sharing}

Knowledge sharing is a process whereby tacit or explicit knowledge communicated to other individuals. Knowledge sharing is the best approach for managing knowledge and should be adopted by all organizations in all conditions/circumstances [4].

Knowledge sharing is a social culture interaction that involves the exchange of employee knowledge, experience and skills through an entire department or organization [7].

According to [8], the importance of

Knowledge Sharing:

1. Knowledge sharing is important in creating new knowledge for competitive advantage.

2. Knowledge sharing is important because of the increased turnover, people do not work at the same job for life anymore. When someone leaves an organization, there are some knowledge from that person that will be gone along with them. Therefore, sharing has the strength to continue knowledge.

3. Many organizations have a problem "we do not know what we know". Skills learned and applied in one part of the organization is not used in other parts.

4. Accelerating change in technology, business and social. For example: 50 percent of what we knew five years ago on this day may be obsolete.

\subsection{Academic Staff}

Academicians, specially lecturers, are teachers and they are the designers of learning experiences, processes, and environment [13]. The academicians are concerned with identifying and then transmitting intellectual content, they more focused on inpiring, motivating, and managing an active learning process by students [14].

\subsection{Organizational Performance}

Knowledge that can be transferred between individuals will not only benefit the organization but also improve the competence of individuals involved in the process [15]. Knowledge sharing is an important factor that affects the development and performance of the organization. Important output of knowledge sharing is the new knowledge and innovations that will improve organizational performance [15]. According to Jone in [15], organizational performance is measured by way of saving time, increasing decision-making, increased customer satisfaction, quality 
improvement and problem solving, improved organizational learning and increase competitive advantage.

\section{Knowledge Sharing Models}

There are several models of knowledge sharing are proposed by several researchers. Research conducted by [3] stated that the sharing of knowledge among the academic staff affected by the following factors:

a. Cultural

b. Motivation to share knowledge

c. Management support

d. Trust

e. Teamwork spirit

f. The degree to which knowledge is considered as a source of power)

According to [9], there are six factors that contribute to the sharing of knowledge as illustrated in figure 1 , namely:

a. Organizational rewards

b. Cultural factors

c. Tacit knowledge

d. IT factors

e. Organizational support

f. Personal trust

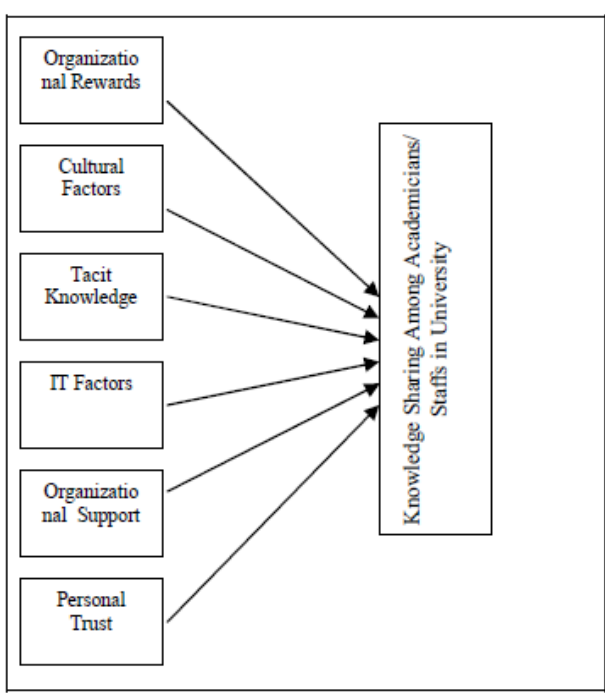

Fig 1. Knowledge sharing model [9]

According to [10], the factors that influence people's decisions to engage in knowledge sharing activities are grouped into three factors as illustrated in figure 2, namely organizational factors, individual factors and technological factors.

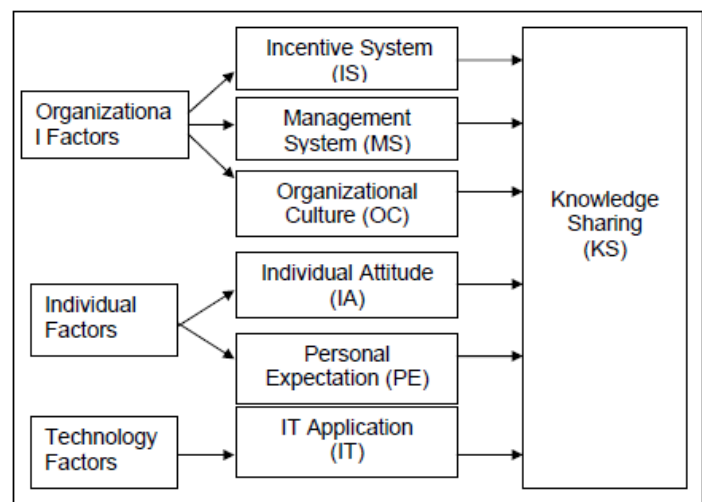

Fig 2. Knowledge sharing model [10]

According to [11], the factors that influence knowledge sharing activities are divided into three factors as illustrated in figure 3: personal factors, organizational factor, and technical factors.

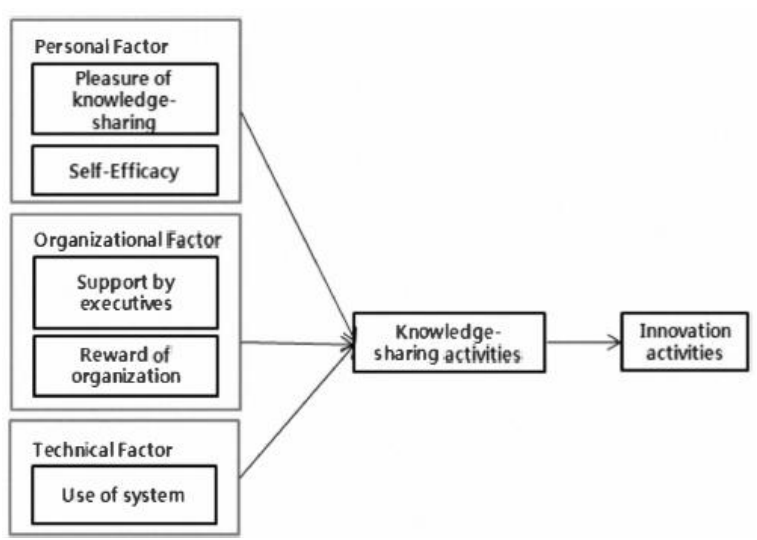

Fig 3. Knowledge sharing model [11]

[12] stated that the factors that influence knowledge sharing among academic staff and their effects on performance in college consisted of four factors as illustrated in figure 4: cultural factors, technological factors, communication and organizational support factors.

\section{Proposed Model}

We proposed a knowledge sharing model for academic staff. The factors that influence knowledge sharing are individual factors, organizational factors, and technological factors.

Based on the figure 6 , the factors influencing knowledge sharing can be explain as follows:

\subsection{Individual Factors}

Eight variables were included in the individual factors are:

1. Awarenes 
The awareness of the importance of knowledge sharing is the attitude that should be owned by every employee, including top management [15]. Objective Self-Awareness (OSA) is defined as state of consciousness in which the individual's attention is focused on him/her. According to Van den Brink in [16], an organization that is at the stage unawareness, not recognizing the contributions of knowledge to their competitors. Argani in [16] stated that awareness at an early stage is crucial for successful knowledge sharing.

2. Trust

Covey in [16] states that trust is the highest human communication and it is the blood of any organization. Because the trust is closely related to knowledge sharing, therefore, the organization must provide an environment that enables staff to trust each other, work together, so that staff are motivated to share knowledge and engage in discussions. In a geographically dispersed organization, electronic communication plays a major role in connecting the organization. However, without belief, geographic location and distance of the organization will be a psychological limitation to the process (Jones and George in [16]).

3. Personality

Personality can be categorized into two types: extravert and introvert (Jung in [16]). According to Jung, introvert people have the more problems in interacting with other people compared to the extravert. Many researchers believe that the ability of the staff to share knowledge, to initially depend on their communication skills both oral and written [17].

4. Motivation

Motivation is crucial when sharing tacit knowledge, it is more difficult than sharing explicit knowledge [18]. To be motivated to share of interest or personal meaning would lead to someone having a more positive attitude towards sharing knowledge [19].

5. Pleasure of sharing

Pleasure of sharing derived from the concept of altruism. Altruism is defined including the discretionary behaviors that help certain people with tasks or problems within the relevant organization (Organ in [20]. Previous research shows that staff who are intrinsically motivated to contribute their knowledge as they engage in intellectual activities and solving problems that are challenging or fun, and because they enjoy helping others (Wasko and Faraj in [20]).

6. Self efficacy

Self efficacy determine the willingness of a person to perform certain activities (Bandura in [21]). The study by [22] argued that individuals environmental contribute to the formulation of satisfaction which leads to the knowledge sharing. Individuals with higher self-efficacy may be more willing to share their knowledge and experience than individuals with low self-efficacy.

7. Willingness to share

Willingness implies a positive attitude towards members of a group, readiness to reply colleagues with friendly. Willingness to share related to a passive way to share knowledge. Someone may be willing to contribute to the collective intellectual capital, although they do not have the inner urge to do so [23].

8. Job satisfaction

Job satisfaction is the overall attitude of the individual work (Hoppock in [24]). Hoppock believe that job satisfaction refers to the subjective response of the employee psychological to work environment. Robbins in [24] argue higher employee satisfaction with their jobs then they will be positive about their own work, and emotional or attitude will produce effects on employee behavior.

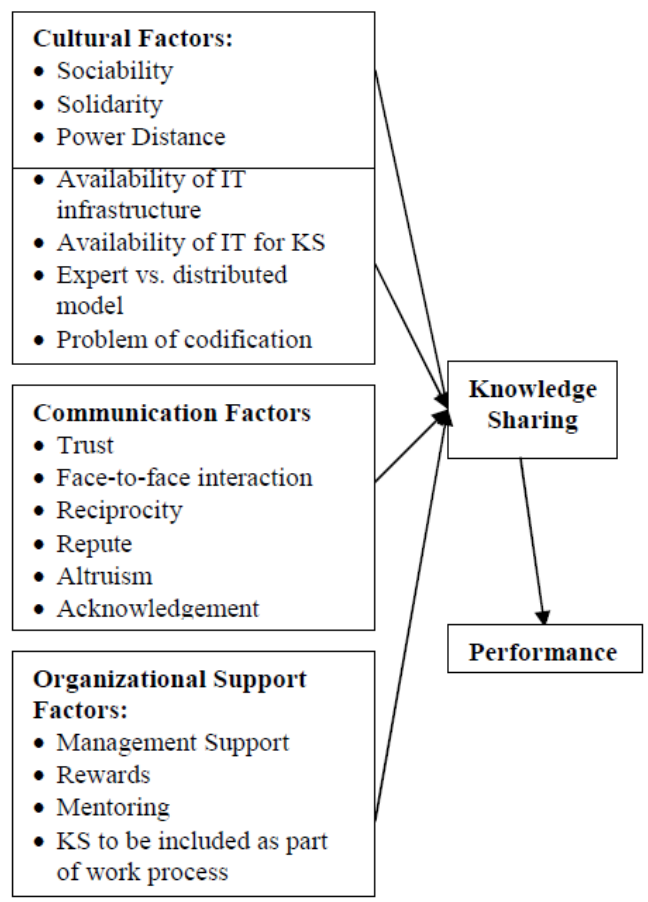

Fig 4. Knowledge sharing model [12] 


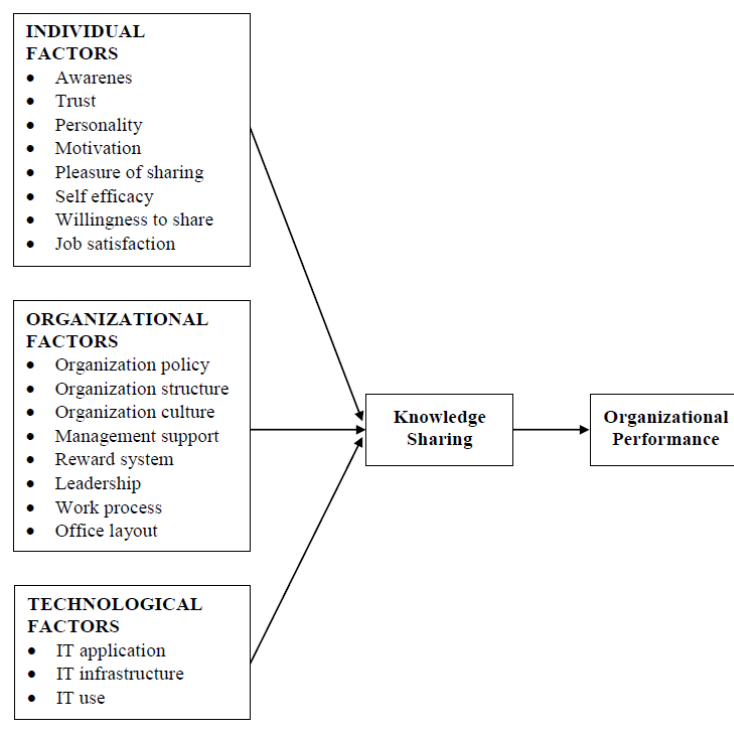

Fig 6. Proposed model

\subsection{Organizational Factors}

Eight variables were included in the organizational factors are:

1. Organization policy

The policies related to knowledge sharing should be applied first before starting knowledge sharing. This will cause the staff to follow existing policies [4].

2. Organization structure

[24] stated that the traditional organizational structure is usually characterized by a layer and lines of responsibility which are complicated by the details of the procedures for reporting certain information. Currently, most managers that aware of the weaknesses in the structure of the bureaucracy will slows down the process and increase the constraints on the flow of information. In addition, such procedures often spend time with sift through every level of knowledge. Syed and Rowland (2004) argues that knowledge sharing will be successful with the support structure that allows the flow of information between divisions with fewer restrictions.

3. Organization culture

Organizational culture can be defined as the shared, the underlying assumption that the organizational learning when face the environment and solving problems of external adaptation and internal integration that are taught to new members as the correct way to solve problems (Park et al in [25]).

4. Management support

Management support is considered as an important influence on organizational knowledge (Cornelly and Kelloway in [20]). Many studies have found that the support of management, it is important to create a climate that supports and provides sufficient resources [20].

5. Reward system

According to Cabrera and Bonache in [20], organizational rewards indicates the value of organizational forms on employee behavior. Reward can rise from monetary incentives such as salary increases and bonuses to nonmonetary rewards such as promotions and job security. According to [2], some organizations have introcuced reward system to encourage employees to share knowledge.

6. Leadership

Leadership is a relationship between the leader and his group, the leadership is to regulate and develop the resources in order to achieve the objectives and also about communicating and sharing experiences and knowledge. Burns in [26] make a distinction between transactional leadership and transformational leadership. Transactional leaders motivate followers through the exchange, such as finishing the job in exchange for a reward. Transformational leaders have a great consideration to interact with his followers to create things that relate to the organization as a whole.

7. Work process

Knowledge sharing among the staff would be more effective if it is incorporated into the work process. According to Anderson in [28], is a difficult thing to capture knowledge because individuals refuse to share knowledge or not competent to pass on their knowledge. Anderson recommends that the best way to make an individual may contribute is to share knowledge as part of the work process.

8. Office layout

Office layout or physical environment within an organization is one of the things that are important in enhancing knowledge sharing. [3] stated that the key aspect of the physical environment including building design and separation between buildings; locations; sizes; types of office; types, amount and nature of the meeting room and others. The physical environment can enhance knowledge sharing by providing an opportunity for employees to meet and share ideas [3].

\subsection{Technological Factors}

Three variables were included in the technological factors are:

1. IT application 
According [27], information technology (IT) is important mediation in knowledge sharing. Application of information technology commonly used to connect employees, interact data and processes that interact to support daily operations, problem solving and decision making within the organization (Whitten et al in [25]).

2. IT infrastructure

Information technology infrastructure, developed to support the needs of an organization's information systems, also facilitates knowledge management. Information technology infrastructure includes data processing, storage, and communications technologies and systems. It is composed of the entire spectrum of an organization's information systems, including transaction processing systems and management information system that consists of databases and data warehouses, and enterprise resource planning systems [4].

3. IT use

Technological factors determining the process of knowledge sharing using ICT (information and communication technology) because ICT enables rapid search, access and retrieval of information and can support communication and collaboration among employees in the organization (Huysman and Wulf in [20]). The use of ICT to facilitate the development of new methods and applications (such as groupware, online databases, intranet, virtual communities, etc.) and allow companies to develop social networks that are available to overcome geographic boundaries and obtain an effective collaboration activities (Pan and Leidner in [2]).

According to Zack in [20], the use of ICT provides three different roles in knowledge management activities:

1. Obtain information.

2. Defining, storing, categorizing, indexing, and linking knowledge related to digital items.

3. Locate and identify related content.

\section{Hypotheses}

Based on model above, we offer the following hypotheses concerning knowledge sharing among academic staff.

H1 Individual factor has a positive effect to knowledge sharing.

H2 Organizational factor has a positive effect to knowledge sharing.
H3 Technological factors has a positive effect to knowledge sharing.

H4 Knowledge sharing has a positive effect to organizational performance.

\section{Conclusion}

This paper proposed a model for knowledge sharing among academic staff. The factors that influencing knowledge sharing are an individual, organization, and technology. Effective knowledge sharing among academic staff can improve the performance of the university.

The research will be followed by empirical study to test the hypotheses and validate the model. The continous research will increas the understanding of knowledge sharing in education sector and its impact on university performance.

\section{Reference}

[1] Amin, S.H.M., Zawawi, A.A., dan Timan, H. "To Share or Not to Share Knowledge: Observing the Factors." Colloquium on Humanities, Science and Engineering Research. IEEE, 2011, pp. 860-864.

[2] Scarbrough, H. "Knowledge management, HRM and innovation process." International Journal of Manpower, 2003, pp. 501-16.

[3] Jain K.K., Sandhu M.S. dan Sidhu G.K. "Knowledge Sharing Among Academic Staff: A Case Study of Business School in Klang Valley, Malaysia.” JASA 2 (2007): 2329

[4] Becerra-Fernandez, I., dan Sabherwal, R. Knowledge Management: Systems and Processes. M.E. Sharpe New York, 2010.

[5] Awad, E.M. dan Ghaziri, H.M. Knowledge management. Pearson Education Inc., New Jersey. 2004.

[6] Tiwana, Amrit. The Knowledge Management Toolkit: Orchestrating IT, Strategy and Knowledge Platform. New Jersey: PrenticeHall, Inc., 2000.

[7] Hogel, M., Parboteeah, K.P. dan Munson, C.L. "Team-level antecedents of individuals knowledge networks." Decision Sciences, 2003.

[8] Gurteen, David. "Creating a Knowledge Sharing Culture." Knowledge Management Magazine. Feb 1999, pp. 1-4.

[9] Azni, A.H., Bakar, A.A., Shah, N., dan Hamid H.A. "Factors Influencing Knowledge Sharing in Higher Learning." IEEE, 2010, pp. 1606-1609. 
[10] Cheng, M.Y., Ho, J.S.Y., dan Lau, P.M. "Knowledge Sharing in Academic Institutions: a Study of Multimedia University Malaysia." Electronic Journal of Knowledge Management, 2009, pp. 313-324.

[11] Lee, J., Kim, J., dan Han, Y. "A Study on Factors Influencing Knowledge-Sharing Activity for the Innovation Activity of Team.” IEEE, 2010, pp. 270-274.

[12] Supar, N., Ibrahim, A.A., Mohamed, Z.A., Yahya, M., dan Abdul, M. "Factors affecting knowledge sharing and its effects on performance: a study of three selected higher academic institutions," Proc. of the International Conference on Knowledge Management (ICKM). University Pertanian Malaysia. Kuala Lumpur, 2005.

[13] Amin, S.H.M., Zawawi, A.A., dan Timan, H. "To Share or Not to Share Knowledge: Observing the Factors." Colloquium on Humanities, Science and Engineering Research. IEEE, 2011, pp. 860-864.

[14] Abdullah, R. dan Selamat, M. H. "Facilitating knowledge sharing with groupware among faculty communities in higher learning institution." International Journal of Computer Science and Network Security, 2007.

[15] Ismail, M.B. dan Yusof, Z.M. "Knowledge Sharing Models: Do They Really Fit Public Organzations?" IEEE, 2008.

[16] Ismail, M.B. and Yusof, Z.M. "The Impact of Individual Factors on Knowledge Sharing Quality." Journal of Organizational Knowledge Management, 2010.

[17] Riege, Andreas. "Three-dozen knowledgesharing barriers managers must consider." Journal of Knowledge Management, 2005, pp. 18-35.

[18] Osterloh, M., \& Frey, B. S. "Motivation, knowledge transfer, and organizational forms." Organization Science, 2000, pp. 538-550.

[19] Gagné, Marylène. "A model of knowledgesharing Motivation." Human Resource
Management, 2009, pp. 571-589.

[20] Lin, H.F. "Knowledge sharing and firm innovation capability: an empirical study." International Journal of Manpower. Emerald Group Publishing Limited, 2007, pp. 315332.

[21] Kwakye, E.O. dan Nor, K.Md. "Individual Factors and Knowledge Sharing." American Journal of Economics and Business Administration, 2011, pp. 66-72.

[22] Endres, M.L., S.P. Endres, S.K. Chowdhury dan I. Alam. "Tacit knowledge sharing, self efficacy theory and application to the open community.” J. Knowl. Manage., 2007, pp. 92-100.

[23] Hooff, Bart dan Hendrix, Linda. "Eagerness and willingness to share: The relevance of different attitudes towards Knowledge sharing." 2004, pp. 1-20.

[24] Wu, C.C., Liu, Y.C., Lin, Y.T., Chou, C.H. "The empirical study of job satisfaction and Knowledge sharing - based on two-factor Motivation theory." Business and Information, 2013, pp. 368-382.

[25] Al-Alawi, A.I., Al-Marzooqi, N.Y., dan Mohammed, Y.F. "Organizational culture and knowledge sharing: critical success factors." Journal of Knowledge Management, 2007, pp. 22-42.

[26] Jahani, S., Ramayah, T., Effendi, A.A. "Is Reward System and Leadership Important in Knowledge Sharing Among Academics?" American Journal of Economics and Business Administration, 2011, pp. 87-94.

[27] Bekele, Rahel dan Abebe, Ermias. "Prospects of Knowledge Sharing Among Ethiopian Institutions of Higher Learning." Ethiopian e-Journal for Research and Inovation Foresight, 2011, pp. 19-35.

[28] Noor, N.M. dan Salim, Juhana. "Factors Influencing Employee Knowledge Sharing Capabilities in Electronic Government Agencies in Malaysia." IJCSI, 2011, pp. 106-114. 